\title{
Oxytocin and vasopressin have no effect on progesterone production and cyclic AMP accumulation by rat luteal cells in vitro
}

\author{
A. K. Mukhopadhyay, A. Kumar*, R. Tams, H. G. Bohnet and \\ F. A. Leidenberger \\ Institute for Hormone and Fertility Disorders, Osterstrasse 86, 2000 Hamburg 20, \\ Federal Republic of Germany
}

\begin{abstract}
Summary. Enzymically dispersed luteal cells obtained from PMSG-hCG-treated immature pseudopregnant rats were incubated with oxytocin and vasopressin. In response to increasing doses of hCG the rat luteal cells produced progesterone and accumulated intracellular cAMP in a dose-dependent manner. A neuropeptide GnRH agonist $\left(4 \times 10^{-6} \mathrm{M}\right.$ ) produced a significant inhibition of hCG-stimulated progesterone production and of accumulation of intracellular cAMP. However, neither the basal nor the hCG-stimulated rate of progesterone production and level of intracellular cAMP was affected by the neurohypophysial peptides tested. Therefore, it is concluded that oxytocin and vasopressin do not have a direct action on steroidogenesis by rat luteal cells.
\end{abstract}

\section{Introduction}

In several species of animals testicular and ovarian steroidogenesis can be modulated by neurohypophysial peptide hormones. Several such peptides, including oxytocin and vasopressin, have been shown by Adashi \& Hsueh (1981) to be inhibitory to hCG-stimulated steroidogenesis in cultured rat Leydig cells. Tan, Tweedale \& Biggs (1982a, b) have reported that oxytocin at a high concentration inhibited basal and hCG-stimulated progesterone production by bovine and human luteal cells, whereas at low concentration it enhanced only the basal rate of steroidogenesis in both types of luteal cells. Oxytocin has been shown to be present in reasonable quantity in ovine (Wathes \& Swann, 1982), bovine (Wathes, Swann, Birkett, Porter \& Pickering, 1983) and human (Wathes et al., 1982; Khan-Dawood \& Dawood, 1983) ovaries. Based on evidence of this type, it has been suggested that oxytocin could play a role in luteal regression. However, there is no report of a direct action of neurohypophysial peptide on rat luteal cells. We have therefore investigated whether oxytocin or vasopressin can influence basal and hCG-stimulated progesterone production or the accumulation of intracellular cAMP by isolated rat luteal cells in vitro.

\section{Materials and Methods}

Materials. The sources of chemicals used in this study were as follows: bovine serum albumin, collagenase (Type IA, $165 \mathrm{U} / \mathrm{mg})$, deoxyribonuclease I $(2000 \mathrm{U} / \mathrm{mg})$, dibutyryl cAMP, GnRH agonist (des Gly ${ }^{10}-\mathrm{D}-\mathrm{Ala}^{6}-\mathrm{N}$-ethylamide $\mathrm{GnRH}$ ), oxytocin (504 i.u./mg) and lysine vasopressin (231 i.u./mg) from Sigma Chemical Company, Munich, Germany; Medium 199, penicillin,

* Present address: Department of Physiology, All India Institute of Medical Sciences, New Delhi, India. 
streptomycin, fungizone and lactalbumin hydrolysate from Grand Island Biological Company, Karlsruhe, Germany; heparin (Liquimin-25000) from Roche, Grenzach-Wyhlen, Germany; hCG from Serono, Freiburg, Germany; PMSG from Ferring, Kiel, Germany; 3-isobutyl-methylxanthine from Aldrich, Beerse, Belgium; and reagents for protein estimation from Bio-Rad, Munich, Germany.

Animals. Wistar rats aged 26 days received a s.c. injection of 50 i.u. PMSG followed $65 \mathrm{~h}$ later by an injection of 25 i.u. hCG. The animals (pseudopregnant) were killed by cervical dislocation on the 9th day after the PMSG injection. Depending on the subsequent requirements for incubation, ovaries from 20-25 PMSG-hCG-treated rats were used in one experiment. The ovaries, consisting mainly of luteal tissue, were removed, freed of fat and adhering tissues, pooled and minced with scissors and incubated in Medium 199 with Earle's salts, glutamine and $25 \mathrm{~mm}$-Hepes, pH 7•4, containing $2 \mathrm{mg}$ collagenase $/ \mathrm{ml}, 10 \mu \mathrm{g}$ DNase $\mathrm{I} / \mathrm{ml}, 4 \mathrm{mg}$ bovine serum albumin $/ \mathrm{ml}, 2 \mathrm{mg}$ lactalbumin hydrolysate $/ \mathrm{ml}, 20 \mathrm{U}$ penicillin $/ \mathrm{ml}, 20 \mu \mathrm{g}$ streptomycin $/ \mathrm{ml}, 0.05 \mu \mathrm{g}$ fungizone $/ \mathrm{ml}$ and $25 \mathrm{U}$ heparin $/ \mathrm{ml}$, at a concentration of $50 \mathrm{mg}$ tissue $/ \mathrm{ml}$ digestion medium. Digestion was carried out under an atmosphere of $95 \% \mathrm{O}_{2}-5 \% \mathrm{CO}_{2}$ at $37^{\circ} \mathrm{C}$ with constant shaking ( 60 cycles $/ \mathrm{min}$ ) for 90 min. The dispersed cells were collected by centrifugation at $100 \mathrm{~g}$ at $4^{\circ} \mathrm{C}$ for $15 \mathrm{~min}$. The cells were washed twice with Medium 199 supplemented as above but without the enzymes (henceforth referred to as Medium 199) to remove any enzyme contamination. The final pellet was resuspended in Medium 199 and cell protein estimated using the Bio-Rad protein estimation kit. The cell suspension was then diluted with Medium 199 to adjust the cellular protein concentration to $800 \mu \mathrm{g}$ protein $/ \mathrm{ml}$.

The viability of the cells thus prepared was over $90 \%$ as assessed by trypan blue exclusion (Tennant, 1964). The cell suspension consisted of single luteal cells, cells in clumps and red blood cells.

Incubation of luteal cells. Incubation of luteal cells was carried out in quadruplicate in a total volume of $0.55 \mathrm{ml}$ containing $200 \mu \mathrm{g}$ protein equivalent of cells, at $37^{\circ} \mathrm{C}$ under an atmosphere of $95 \% \mathrm{O}_{2}$ and $5 \% \mathrm{CO}_{2}$ for a period of $3 \mathrm{~h}$. Test substances were diluted in Medium 199 before addition. The incubations were terminated by placing the tubes in an ice-water bath followed by addition of ice-cold $0.1 \mathrm{M}$-phosphate-buffered saline, $\mathrm{pH} 7 \cdot 0$. The tubes were centrifuged at $1500 \mathrm{~g}$ for $20 \mathrm{~min}$ and the supernatant stored frozen at $-20^{\circ} \mathrm{C}$ until the progesterone content was measured by radioimmunoassay. The cell pellet was extracted with $1.0 \mathrm{M}$-perchloric acid for intracellular cAMP determination. In experiments in which intracellular cAMP was measured the incubation mixture contained $0.5 \mathrm{~mm}$-3-isobutyl-methylxanthine, a phosphodiesterase inhibitor.

Radioimmunoassay of progesterone. Progesterone concentration in the supernatant was measured by using a commercial radioimmunoassay kit supplied by Radioassay Systems Laboratories, Carson, CA, U.S.A. According to the information provided with the kit the following materials were checked for cross-reactivity (the percentages indicate cross-reactivity at $50 \%$ displacement compared to progesterone): progesterone, $100 \% 20 \alpha$-dihydroprogesterone, $6.25 \%$; desoxycorticosterone, $3.2 \%$; corticosterone, $0.42 \% ; 17 \alpha$-hydroxyprogesterone, $0.15 \%$; pregnenolone, $0.06 \%$; androstendione, $0.04 \%$; testosterone, $0.03 \%$ and 11 -deoxycortisol, pregnenolone sulphate, cholesterol dihydroepiandrosterone, oestradiol-17 $\beta$, oestrone, oestriol, androsterone, aldosterone and cortisol, all $<0.01 \%$. The sensitivity of the assay, defined as the minimum detectable amount, was $\mathbf{0 . 2} \mathrm{ng}$ progesterone $/ \mathrm{ml}$. Inter- and intra-assay coefficients of variation were $<8 \%(n=16)$ and $5 \%(n=20)$ respectively. Progesterone concentration is expressed as $n g$ progesterone per $200 \mu \mathrm{g}$ protein equivalent of luteal cells per $3 \mathrm{~h}$.

Radioimmunoassay of $C A M P$. Intracellular cAMP was extracted from the cell pellet by adding $500 \mu 11.0 \mathrm{M}$-perchloric acid followed by thorough mixing, incubation at $4^{\circ} \mathrm{C}$ for $30 \mathrm{~min}$ and centrifugation at $1500 \mathrm{~g}$ for $10 \mathrm{~min}$ at $4^{\circ} \mathrm{C}$. The supernatant obtained was neutralized by adding $500 \mu \mathrm{l}$ $0.71 \mathrm{M}-\mathrm{K}_{3} \mathrm{PO}_{4}$ and centrifuged. The clear supernatant obtained was radioimmunoassayed for 
cAMP by the method of Steiner, Parker \& Kipnis (1972) as described by Schumacher, Schaefer, Lichtenberg \& Hilz (1979). The sensitivity of the assay was $5 \mathrm{fmol} \mathrm{cAMP/tube.} \mathrm{Interassay} \mathrm{variation}$ was $<10 \%(n=10)$ and intra-assay variation was $<5 \%(n=10)$.

Statistical analysis. The statistical significance of the observed differences was determined by Student's $t$ tests.

\section{Results}

As shown in Text-fig. 1, the production of progesterone and accumulation of intracellular cAMP were stimulated by hCG in a dose-dependent manner. However, neither oxytocin nor vasopressin, added in doses up to $4 \times 10^{-6} \mathrm{M}$ (equivalent to 2 i.u. oxytocin $/ \mathrm{ml}$ and 1 i.u. vasopressin $/ \mathrm{ml}$ ) had any significant effect on basal rate of steroidogenesis or the level of intracellular cAMP.

The effects of oxytocin, vasopressin and a GnRH agonist on hCG-stimulated steroidogenesis and intracellular cAMP formation were studied. The dose of hCG used was submaximal, as it is known that GnRH can inhibit gonadotrophin-stimulated steroidogenesis only when a submaximal dose of hCG is used, and that at a supramaximal dose of hCG, GnRH is ineffective (Clayton, Harwood \& Catt, 1979). In the experiment in which progesterone was measured, hCG was used at a dose of $25 \mathrm{mi}$.u. and in the other part of the experiment, in which cAMP was measured, a dose of 2.5 mi.u. hCG was used. These two doses of hCG were selected on the basis of the data in Text-fig. 1 .

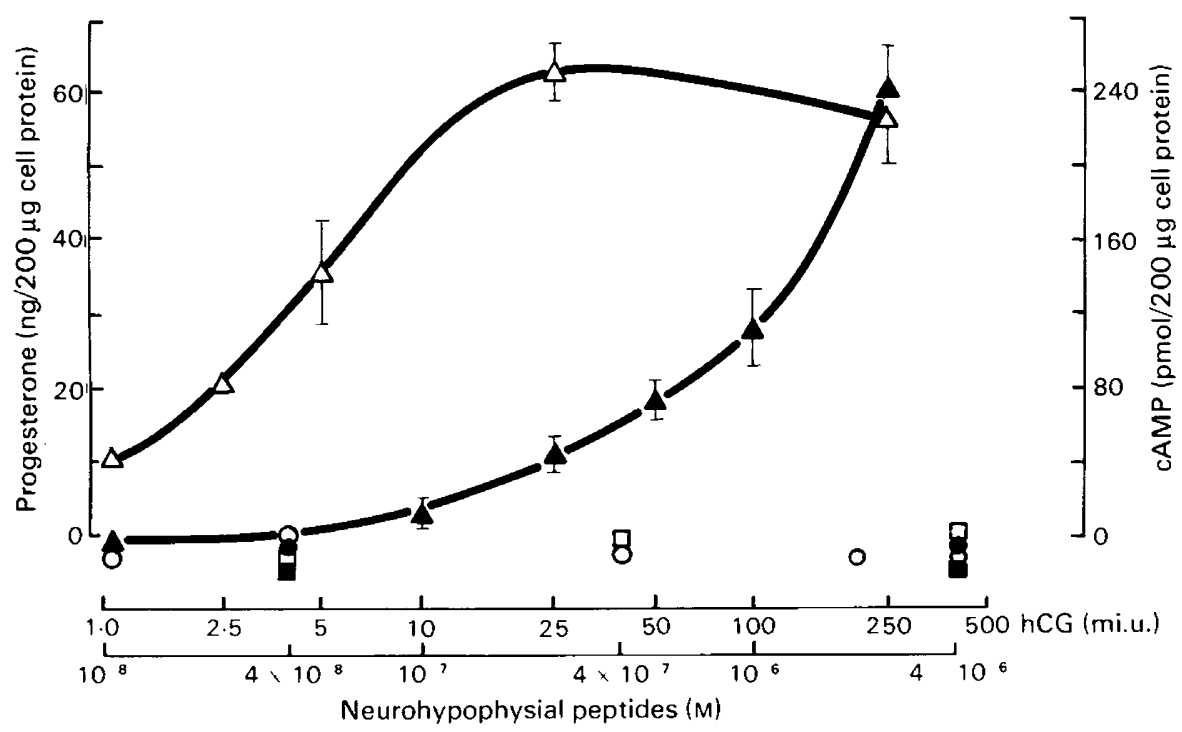

Text-tig. 1. Response of rat luteal cells to the addition of increasing doses of hCG, oxytocin and vasopressin. The luteal cells were incubated in Medium 199 under an atmosphere of $95 \%$ air and $5 \% \mathrm{CO}_{2}$ in presence of various doses of $h C G(\triangle, \Delta)$, oxytocin $(O, O)$ and vasopressin $(\square, \square)$ for $3 \mathrm{~h}$ and the progesterone $(\triangle, O, \square)$ produced and intracellular $\operatorname{cAMP}(\boldsymbol{\Delta}, \boldsymbol{O}, \boldsymbol{\square})$ accumulated were measured in quadruplicate incubations. The results shown represent mean \pm s.d. (vertical bars); vertical bars are omitted when the s.d. was smaller than the symbol. Each value presented is the concentration measured, corrected by subtracting the basal amount estimated in the absence of any addition. The basal amounts of progesterone produced and intracellular cAMP accumulated were $11.3 \pm 0.6 \mathrm{ng}$ and $17.3 \pm 3.8 \mathrm{pmol}$ per $200 \mu \mathrm{g}$ cell protein respectively. The concentration of $4 \times 10^{-6} \mathrm{M}$ was equivalent to 1 i.u. vasopressin $/ \mathrm{ml}$ and 2 i.u. oxytocin $/ \mathrm{ml}$. 
Table 1. Effect of addition of oxytocin, vasopressin and GnRH agonist on hCG-stimulated progesterone production and accumulation of intracellular cAMP in rat luteal cells

\begin{tabular}{lcc}
\hline \multicolumn{1}{c}{ Additions } & $\begin{array}{c}\text { Progesterone } \\
\text { (ng/200 } \mu \text { g protein) }\end{array}$ & $\begin{array}{c}\text { Intracellular cAMP } \\
\text { (pmol/200 } \mu \mathrm{g} \text { protein) }\end{array}$ \\
\hline None & $9 \cdot 05 \pm 2 \cdot 02$ & $17 \cdot 29 \pm 3 \cdot 81$ \\
hCG & $45 \cdot 44 \pm 7.05 *$ & $62 \cdot 22 \pm 9 \cdot 63^{*}$ \\
hCG + oxytocin & $49 \cdot 41 \pm 1.75$ & $65.79 \pm 12 \cdot 47$ \\
hCG + vasopressin & $49 \cdot 21 \pm 4.04$ & $54 \cdot 74 \pm 5 \cdot 74$ \\
hCG + GnRH & $20 \cdot 15 \pm 1.27 \ddagger$ & $45 \cdot 10 \pm 2 \cdot 27 \dagger$ \\
\hline
\end{tabular}

Values are mean \pm s.d. for quadruplicate determinations.

* $P<0.001$ compared to control group.

$\dagger P<0.05 ; \ddagger P<0.001$ compared to hCG-treated group.

The results (Table 1) indicate that neither oxytocin $\left(4 \times 10^{-6} \mathrm{M}\right)$ nor vasopressin $\left(4 \times 10^{-6} \mathrm{M}\right)$ had any effect on hCG-stimulated steroidogenesis and intracellular cAMP formation. On the other hand GnRH agonist $\left(4 \times 10^{-6} \mathrm{M}\right)$ produced a significant inhibition of hCG-stimulated progesterone production and of intracellular cAMP formation. Lower doses $\left(4 \times 10^{-9}-4 \times 10^{-7} \mathrm{M}\right)$ of oxytocin and vasopressin have also been used to investigate the effects on hCG-stimulated steroidogenesis but were found to be ineffective ( $R$. Tams, unpublished observations). Each experiment was repeated at least twice and some experiments were also repeated using oxytocin from Serva (Heidelberg, Germany). The results obtained were similar to those presented here. The negative data were also reproducible between several different preparations of luteal cells.

\section{Discussion}

Ott \& Scott (1910) were the first to suggest that oxytocin-like activity was associated with the corpus luteum when they reported that administration of luteal extract to goats enhanced the milk-ejection response. Neurohypophysial peptides have now been shown to be present in the ovary of several animal species (Wathes et al., 1982, 1983; Wathes \& Swann, 1982; Khan-Dawood \& Dawood, 1983). However, physiological functions of such ovarian oxytocin have yet to be elucidated. It has been suggested that the ovarian oxytocin could have an intraovarian function and act directly at the luteal cells, thereby effecting rapid luteal regression (Tan et al., 1982a, b). Flint \& Sheldrick (1983), on the other hand, suggested that ovarian oxytocin may be indirectly responsible for luteal regression by enhancing the secretion of uterine prostaglandins.

The results obtained in the present study do not support the view that neurohypophysial peptides directly modulate steroidogenesis by the luteal cells, at least in the rat. The luteal cells obtained by enzymic dispersion of ovaries from immature pseudopregnant rats responded, in a dose-dependent manner, to stimulation by hCG in terms of both progesterone production and accumulation of intracellular cAMP. The GnRH agonist, at a dose of $4 \times 10^{-6} \mathrm{M}$, significantly inhibited progesterone production and intracellular cAMP formation, as previously reported (Clayton et al., 1979; Behrman, Preston \& Hall, 1980). However, in contrast to bovine (Tan et al., 1982a) and human (Tan et al., 1982b) luteal cells, the rat luteal cells did not respond to low or high doses of oxytocin used. Vasopressin was also without any effect. Furthermore, neither oxytocin nor vasopressin, used at doses equimolar to that of $\mathrm{GnRH}$ showing an antigonadotrophic effect, could modify the response of rat luteal cells to the stimulation by hCG. It may be concluded, therefore, that the luteal cells of the rat are insensitive to a direct action by the neurohypophysial peptides, oxytocin and vasopressin. Possibly the direct action of oxytocin on the luteal cells is limited to certain species of animals only, or at a particular physiological state, e.g. during early pregnancy only as shown by Tan et al. (1982a). 
When an effect of GnRH has been reported for the testis, it is also found in the ovary, as in the case of rat (Hsueh \& Jones, 1981). However, although an inhibitory effect of neurohypophysial peptides on cultured rat testicular cells has been reported (Adashi \& Hsueh, 1981), no effect on rat luteal cells was observed in the present study.

We thank Dr M. Schumacher for the gift of a highly specific antiserum to cAMP and for helpful discussions; Mrs R. Schacht for expert technical assistance and Mrs A. de Somogyi for typing the manuscript.

\section{References}

Adashi, E.Y. \& Hsueh, A.J.W. (1981) Direct inhibition of testicular androgen biosynthesis revealing antigonadal activity of neurohypophysial hormones. Nature, Lond. 293, 650-652.

Behrman, H.R., Preston, S.L. \& Hall, A.K. (1980) Cellular mechanism of the antigonadotropic action of luteinizing hormone releasing hormone in the corpus luteum. Endocrinology 107, 656-664.

Clayton, R.N., Harwood, J.P. \& Catt, K.J. (1979) Gonadotrophin-releasing hormone analogue binds to luteal cells and inhibits progesterone production. Nature, Lond. 282, 90-92.

Flint, A.P.F. \& Sheldrick, E.L. (1983) Evidence for a systemic role for ovarian oxytocin in luteal regression in sheep. $J$. Reprod. Fert. 67, 215-225.

Hsueh, A.J.W. \& Jones, P.B.C. (1981) Extrapituitary actions of gonadotropin-releasing hormone. Endocr. Rev. 2, 437-461.

Khan-Dawood, F.S. \& Dawood, M.Y. (1983) Human ovaries contain immunoreactive oxytocin. J. clin. Endocr. Metab. 57, 1129-1132.

Ott, I. \& Scott, J.C. (1910) The galactogogue action of the thymus and corpus luteum. Proc. Soc. exp. Biol. Med. 8, 49-50.

Schumacher, M., Schaefer, G., Lichtenberg, V. \& Hilz, H. (1979) Maximal steroidogenic capacity of mouse leydig cells. FEBS Letters 107, 398-402.
Steiner, A.L., Parker, C.W. \& Kipnis, D.M. (1972) Radioimmunoassay for cyclic nucleotides. I. Preparation of antibodies and iodinated cyclic nucleotides. $J$. biol. Chem. 247,1106-1113.

Tan, G.J.S., Tweedale, R. \& Biggs, J.S.G. (1982a) Effects of oxytocin on the bovine corpus luteum of early pregnancy. J. Reprod. Fert. 66, 75-78.

Tan, G.J.S., Tweedale, K. \& Biggs, J.S.G. (1982b) Oxytocin may play a role in the control of the human corpus luteum. J. Endocr. 95, 65-70.

Tennant, J.R. (1964) Evaluation of the trypan blue technique for the determination of cell viability. Transplantation 2, 685-694.

Wathes, D.C. \& Swann, R.W. (1982) Is oxytocin an ovarian hormone? Nature, Lond. 297, 225-227.

Wathes, D.C., Swann, R.W., Pickering, B.T., Porter, D.G., Hall, M.G.R. \& Drife, J.O. (1982) Neurohypophysial hormones in the human ovary. Lancet ii, 410 412.

Wathes, D.C., Swann, R.W., Birkett, S.D., Porter, D.G. \& Pickering, B.T. (1983) Characterization of oxytocin, vasopressin and neurophysin from the bovine corpus luteum. Endocrinology 113, 693-698.

Received 19 January 1984 